\title{
Awareness of Natural and Man-Made Radiation and Their Effects among Patients Awaiting Radiological Investigations
}

\author{
Dr. Alagbe Olayemi Atinuke MBBS FWACS ${ }^{1 *}$, Dr. Abodunrin Olugbemiga Lanre MBBS FWACP ${ }^{2}$ \\ ${ }^{1}$ Department of radiology, LAUTECH Teaching Hospital, PMB 5000, Osogbo, Osun State, Nigeria \\ ${ }^{2}$ Department of Community Medicine, Faculty of Clinical Sciences, College of Health Sciences, Ladoke Akintola University of Technology \\ (LAUTECH), PMB 4400, Osogbo, Osun State, Nigeria
}

DOI: $10.36348 /$ sjnhc.2020.v03i02.008

| Received: 20.08.2019 | Accepted: 27.08.2019 | Published: 29.02.2020

*Corresponding author: Alagbe Olayemi Atinuke

\section{Abstract}

Individuals undergoing radiological investigations are exposed to natural and man-made radiation which could be ionizing or non-ionizing. This study aimed at assessing the knowledge of radiation and practice of radiation protection measures among patients awaiting radiological investigations at a teaching hospital in Southwest Nigeria. Consenting patients awaiting investigations at the radiology department of LAUTECH teaching hospital were enrolled for this study. Semi-structured interviewer-administered questionnaire were used and knowledge scoring was done. The data were analyzed using Statistical Package for Social Scientists (SPSS) version 22 and $\mathrm{p}<0.05$ were considered statistically significant. The mean knowledge of radiation score among the 200 patients studied was $55.8 \% \pm 20.8$. Participants with high education had significantly higher score $(62.46 \% \pm 15.07)$ than those with low and no formal education $(34.79 \% \pm 22.38) \mathrm{p}=0.001$. Participants who practiced personal protective measures had higher scores than those that do not $\mathrm{p}=0.001$. However, there was no statistically significant difference in the knowledge scores between the males and females $(55.59 \% \pm 20.41$ vs $56.14 \% \pm 21.35) \mathrm{p}>0.05$. This study showed that knowledge about radiation helps in adopting a lifestyle that protects from radiation but the knowledge of participants about radiation appears to be shallow. Patients were not aware of the type of radiological investigation they undergo and the associated radiation risk. It is strongly recommended that patient should be well informed about the radiological investigations they undergo.

Keywords: Radiation, Ionizing radiation, Non-ionizing radiation, Knowledge, Practice.

\begin{abstract}
Copyright @ 2020: This is an open-access article distributed under the terms of the Creative Commons Attribution license which permits unrestricted use, distribution, and reproduction in any medium for non-commercial use (NonCommercial, or CC-BY-NC) provided the original author and source are credited.
\end{abstract}

\section{INTRODUCTION}

Radiation can be defined as the energy from a source that travels through some materials or through space. This can be ionizing or non-ionizing and natural or man-made. Non-ionizing radiation refers to the type of electromagnetic radiation that does not carry enough energy per quantum to ionize atoms or molecules [1]. Examples of non-ionizing radiation are near ultraviolet light, visible light, infrared, microwave, radio waves, and low-frequency radio-waves [2].

On the other hand, ionizing radiation has a higher frequency and shorter wavelength $(<100 \mathrm{~nm})$ than non-ionizing radiation and can cause damage when it interacts with matter [3]. Far ultraviolet light, X-rays, gamma-rays, and all particle radiation from radioactive decay are examples of ionizing radiation. Ionizing radiation has many uses especially in medical imaging but can cause health hazards like burns, radiation sickness, cancer and genetic damage. Non-ionizing radiation is also capable of causing non-thermal biological damage similar to ionizing radiation [2].

The level of public awareness of the detrimental effects of ionizing radiation is still a concern and a high percentage of individuals are not aware of this. Among those aware of radiation, many cannot appropriately differentiate between ionizing and non-ionizing radiation and their detrimental health effects. Hence, they are not concerned about safety measures [4-7].

Individuals undergoing radiological investigations that utilize ionizing radiation are exposed to both natural and man-made radiation that is they are at risk of additional radiation exposure than the general populace. This study assessed the knowledge of individuals on both natural and man-made radiation as well as the influence of this knowledge on the adoption of radiation protection practices. The outcome may help to reduce the burden of radiation hazards. 


\section{METHODS}

This descriptive cross-sectional study was conducted at the radiology department of LAUTECH teaching hospital Ogbomosho, Oyo state, Nigeria. Patients awaiting radiological investigations (radiography/radiographic procedures, ultrasonography and computed tomographic scan) were selected by a simple random technique. This study was carried out using semi-structured interviewer-administered questionnaires made up of 3 sections; Sociodemographic pattern of respondents, knowledge of the respondents about the sources and effects of radiation and practice of radiation protection measures. Patients on admission, acute or critically ill and those below 15 years were excluded in this study.

The questionnaires were manually sorted out, checked for errors and data entered into the computer. Analysis was done using Statistical Package for Social Sciences (SPSS) version 22. Frequency tables were generated and test of statistical association were carried out by chi-square. The level of significance was set at $\mathrm{p}<0.05$. Ten questions were assessed, maximum score of 5 marks and a minimum score of zero allotted to each question; awareness of radiation, awareness of ionizing and non ionizing radiation, knowledge of classification of radiation in to natural or manmade, knowledge of sun as the most common source of radiation, classification of the sources of radiation, knowledge of safety of ultrasound in pregnancy, knowledge of the health effects of the radiation, knowledge of exposure to radiation at home and community, knowledge that excessive exposure to sun causes skin cancer and knowledge of radiation protection measures.

\section{RESULTS}

Of the two hundred participants in this study 85 were females and 115 were males, and they were between 15 and 70 years. The socio demographic characteristics of the patients are shown in Table-1.

Table-1: Socio-demographic characteristics of respondents

\begin{tabular}{|l|l|l|}
\hline Age group (years) & $\mathbf{N = 2 0 0}$ & Frequency \% \\
\hline $15-29$ & 142 & 71 \\
\hline $30-44$ & 32 & 16 \\
\hline $45-59$ & 12 & 6 \\
\hline $60-74$ & 14 & 7 \\
\hline Gender & & \\
\hline Males & 115 & 57.5 \\
\hline Females & 85 & 42.5 \\
\hline Educational status & & \\
\hline No formal education & 17 & 8.5 \\
\hline Primary education & 18 & 9 \\
\hline Secondary education & 13 & 6.5 \\
\hline Tertiary education & 152 & 76 \\
\hline Tribe & & \\
\hline Yoruba & 184 & 92 \\
\hline Igbo & 14 & 7 \\
\hline Hausa & 2 & 1 \\
\hline Marital status & & \\
\hline Single & 139 & 69.5 \\
\hline Married & 61 & 30.5 \\
\hline Religion & & \\
\hline Christianity & 136 & 66 \\
\hline Islam & 66 & 33 \\
\hline Traditional & 2 & 1 \\
\hline & & \\
\hline
\end{tabular}

The mean age of patients was 29 years with a range of 15 to 70 years; most of the patients were between 20 and 39 years. Eighty five (42.5\%) were females and $115(57.5 \%)$ were males. Most of the patients $(76 \%)$ belong to tertiary education category. Majority of the patients were of the Yoruba tribe, single and Christians.

Table-2: Patients' knowledge of radiation and the sources of radiation

\begin{tabular}{|c|c|c|}
\hline Variable & Frequency & Percentage \\
\hline $\begin{array}{c}\text { Awareness of radiation } \\
\text { Yes } \\
\text { No } \\
\text { Don't know }\end{array}$ & $\begin{array}{l}174 \\
6 \\
20\end{array}$ & $\begin{array}{l}87 \\
3 \\
10\end{array}$ \\
\hline $\begin{array}{c}\text { Awareness of ionizing radiation } \\
\text { Yes } \\
\text { No } \\
\text { Don't know } \\
\end{array}$ & $\begin{array}{l}40 \\
70 \\
90 \\
\end{array}$ & $\begin{array}{l}20 \\
35 \\
45 \\
\end{array}$ \\
\hline $\begin{array}{c}\text { Awareness of non-ionizing radiation } \\
\text { Yes } \\
\text { No } \\
\text { Don't know } \\
\end{array}$ & $\begin{array}{l}38 \\
56 \\
106 \\
\end{array}$ & $\begin{array}{l}19 \\
28 \\
53 \\
\end{array}$ \\
\hline $\begin{array}{c}\text { Awareness of natural and manmade radiation } \\
\text { Yes } \\
\text { No } \\
\text { Don't know }\end{array}$ & $\begin{array}{l}146 \\
4 \\
50\end{array}$ & $\begin{array}{l}73 \\
2 \\
25\end{array}$ \\
\hline $\begin{array}{l}\text { Source of information } \\
\text { Health personnel } \\
\text { Educational exposure } \\
\text { friends }\end{array}$ & $\begin{array}{l}38 \\
128 \\
9\end{array}$ & $\begin{array}{l}19 \\
64 \\
4.5 \\
\end{array}$ \\
\hline
\end{tabular}




\begin{tabular}{|c|l|l|}
\hline Knowledge about natural sources dominance & & \\
Yes & 115 & 57.5 \\
No & 48 & 24 \\
Don't know & 37 & 18.5 \\
\hline Knowledge score & & \\
Poor knowledge $<50$ & 53 & 26.5 \\
Good knowledge $\geq 50$ & 147 & 73.5 \\
\hline
\end{tabular}

While majority of the patients $174(87 \%)$ were aware of radiation, only a fifth was aware of ionizing and non-ionizing radiation. Most of the patients $(73 \%)$ knew that radiation can be natural or manmade, and 161 $(80.5 \%)$ patients indicated that the sun is the most common source of natural radiation (Table-2).

Table-3: Patients' response on biological effects of radiation

*Correct options

\begin{tabular}{|l|l|l|l|}
\hline Effects & Non-ionizing & Ionizing & Don't know \\
\hline Cataract & $20(10 \%)^{*}$ & $16(8 \%)$ & $164(82 \%)$ \\
\hline Skin burns & $34(17 \%)^{*}$ & $68(34 \%)^{*}$ & $98(49 \%)$ \\
\hline Heating of body tissue & $55(27.5 \%)^{*}$ & $47(23.5 \%)$ & $98(49 \%)$ \\
\hline radiation sickness & $10(5 \%)$ & $81(40.5 \%)^{*}$ & $109(54.5 \%)$ \\
\hline Cancer & $24(12 \%)$ & $61(30.5 \%)^{*}$ & $115(57.5 \%)$ \\
\hline genetic damage & $11(5.5 \%)$ & $53(23.5 \%)^{*}$ & $136(68 \%)$ \\
\hline Fetal anomaly & $13(6.5 \%)$ & $47(23.5 \%)^{*}$ & $140(70 \%)$ \\
\hline Fetal death & $14(7 \%)$ & $42(21 \%)^{*}$ & $144(72 \%)$ \\
\hline Abortion & $20(10 \%)$ & $37(18.5 \%)$ & $143(71.5 \%)$ \\
\hline Mental retardation & $20(10 \%)$ & $41(20.5 \%)$ & $139(69.5)$ \\
\hline Cold & $24(12 \%)$ & $30(15 \%)$ & $146(73 \%)$ \\
\hline Headache & $25(12.5 \%)$ & $38(19 \%)$ & $137(68.5 \%)$ \\
\hline Fracture & $21(49 \%)$ & $36(18 \%)$ & $143(71.5 \%)$ \\
\hline
\end{tabular}

Cold, headache and fracture are not effects of radiation

Majority of patients do not know the biological effects of radiation. Most patients (164) did not know that cataract could result from of non-ionizing radiation. One third $(30.5 \%)$ indicated that ionizing radiation can cause cancer; while $57.5 \%$ did not know cancer could be sequelae of radiation exposure. Interestingly, some patients stated that cold, headache and fracture are health effects of radiation (Table-3).

Table-4: Association between knowledge score and socio-demographic factors of the patients

\begin{tabular}{|c|c|c|c|c|c|}
\hline \multirow[t]{2}{*}{ Variable } & \multicolumn{2}{|c|}{ Knowledge score } & \multirow[t]{2}{*}{ Chi square } & \multirow[t]{2}{*}{$d f$} & \multirow[t]{2}{*}{ p value } \\
\hline & $\begin{array}{l}\text { Poor }(<50 \%) \\
\mathrm{n}(\%)\end{array}$ & $\begin{array}{l}\text { Good (>50\%) } \\
\mathrm{n}(\%)\end{array}$ & & & \\
\hline \multicolumn{6}{|l|}{ Age group(years) } \\
\hline $15-29$ & $29(20.4)$ & $113(79.6)$ & 11.083 & 3 & $0.011 * *$ \\
\hline $30-44$ & $11(34.4)$ & $21(65.5)$ & & & \\
\hline $45-59$ & $6(50.0)$ & $6(50.0)$ & & & \\
\hline $60-74$ & $7(50.0)$ & $7(50.0)$ & & & \\
\hline Gender & & & & & \\
\hline Male & $32(27.8)$ & $83(72.2)$ & 0.244 & 1 & 0.632 \\
\hline Female & $21(24.7)$ & $64(75.3)$ & & & \\
\hline Educational status & & & & & \\
\hline Secondary and below & $28(58.3)$ & $20(41.7)$ & 32.859 & 1 & $0.001 * *$ \\
\hline Tertiary and above & $25(16.4)$ & $127(83.6)$ & & & \\
\hline Marital status & & & & & \\
\hline Single & $29(20.9)$ & $110(79.1)$ & 7.434 & 1 & $0.006 * *$ \\
\hline Married & $24(39.3)$ & $34(60.7)$ & & & \\
\hline Tribe & & & & & \\
\hline Yoruba & $49(26.6)$ & $135(73.4)$ & & & \\
\hline Ibo & $3(21.4)$ & $11(78.6)$ & 0.754 & 2 & 0.747 \\
\hline Hausa & $1(50.0)$ & $1(50.0)$ & & & \\
\hline Religion & & & & & \\
\hline Christianity & $37(28.0)$ & $95(72.0)$ & & & \\
\hline Islam & $15(22.7)$ & $51(77.3)$ & 1.208 & 2 & 0.429 \\
\hline Traditional & $1(50.0)$ & $1(50.0)$ & & & \\
\hline
\end{tabular}

*Fischer's exact test 
**Statistically significant

Table-4 shows the association between sociodemographic factors and knowledge score of the respondents. There was statistically significant association between educational status and knowledge score. One hundred and twenty-seven (83.6\%) respondents who had tertiary/higher education had good knowledge score while $41.7 \%$ of those who had secondary/lower education had good knowledge score ( $p$ value $=0.001$ ). There was no significant association between knowledge score and other factors such as gender, tribe and religion.

Table-5: Association between knowledge score and adoption of personal radiation protection practices

\begin{tabular}{|l|l|l|l|l|l|}
\hline Groups & Good knowledge & Poor knowledge & Chi square & $\boldsymbol{d} f$ & P value \\
\hline Avoid sun & $120(81.6)$ & $17(32.1)$ & 44.338 & 1 & 0.001 \\
Don't avoid sun & $27(18.4)$ & $36(67.9)$ & & & \\
\hline Use sun shade & $103(83.1)$ & $21(16.9)$ & 15.326 & 1 & 0.001 \\
Don't use sun shade & $44(57.9)$ & $32(42.1)$ & & & \\
\hline Avoid high tension cable & $109(90.8)$ & $11(9.2)$ & 46.276 & 1 & 0.001 \\
Don't avoid high tension cables & $38(47.5)$ & $42(52.5)$ & & & \\
\hline
\end{tabular}

There was statistically significant association between knowledge score and adoption of personal radiation protection practice such as avoidance of sun, use of sun shade and avoidance of high tension cables $(\mathrm{p}=0.001)($ Table-5).

Table-6: Patients' education by physician or radiation worker

\begin{tabular}{|l|l|l|}
\hline Patient education by a doctor or radiation workers & Frequency & Percentage\% \\
Indication for study & 184 & 92 \\
Radiation risk & 0 & 0 \\
Type of investigation & 2 & 1 \\
\hline
\end{tabular}

Surprisingly, only a few (1\%) of the patients was informed about the type of radiological investigation they underwent and all of the patients reported that neither the referring physician nor the radiation worker educated them on the radiation risk associated with the investigation (Table-6).

\section{DISCUSSION}

This study revealed the awareness of radiation in the general term among the participants, but there is poor knowledge of the types of radiation, biological effects of radiation and radiation safety measures. Most patients that had good knowledge of the radiation were in the tertiary education category. This supports the fact that knowledge of radiation differs with level of educational exposure [8]. Similar to a previous study, the patients indicated that natural radiation especially from sun dominates human exposure [9].

Only $10.5 \%$ of the patients stated that they are at risk of radiation exposure from radiological investigations. This may be due to the failure of the referring doctor and radiation worker to educate the patient on the type of requested investigation and radiation risk as revealed in this study. The radiation risk should be properly communicated to the patient.

Similar to a study in Hong Kong, a majority of the respondents in this present study were informed of the indication of the radiological investigation [5]. Contrary to the former study where $42.7 \%$ were informed of the radiation risk, none of the respondent in this present study was told of the radiation risk [5].
Lack of patient education on radiation risk could be due to poor knowledge of the referring physician about the radiation doses of the requested radiological examinations [10-12]. This is buttressed by a study that reported the average mean dose of radiation as six times the quantity estimated by the doctors [13].

As previously known, this study revealed poor knowledge of the harmful biological effects of radiation emphasizing that the level of public awareness of the detrimental effects of ionizing radiation is still a concern [4-7]. The lack of immediate adverse effect of ionizing radiation except in cases of high intensity that produces heat could account for the poor awareness.

Two-thirds of the patients do not know that ionizing radiation causes cancer and genetic damage. While $12 \%$ and $5.5 \%$ believed they are caused by nonionizing radiation. This is contrary to a study that revealed $73.2 \%$ of the participant study perceived that cancer is an adverse effect of ionizing radiation [14].

Eighty-two percent of the participants do not know that radiation can cause cataract. Cataracts account for approximately $50 \%$ of the cases of blindness worldwide [15]. Cortical cataract has been linked with natural background radiation from the sun [16]. Other ocular diseases, such as pterygium and climatic droplet keratopathy have also been linked to radiation [17-19].

Majority of the patients was aware that excessive exposure to sun can cause skin cancer and 
reported that those at risk of prolonged stay under the sun include outdoor workers such as farmers, hawkers, traffic warders and road side petty traders. Similarly, a study in South Africa which investigated White Cape Town beachgoers revealed as high as $90 \%$ of respondents citing skin cancer as a potential adverse effect of excess exposure to sun [20]. Sun exposure is the major environmental risk factor for melanoma and for the non-melanoma skin cancers (NMSCs), basal cell carcinoma and squamous cell carcinoma [11, 21-24].

This study also revealed the association between knowledge score and the adoption of personal radiation protection practices. Avoidance of prolonged stay under the sun and high tension cables; use of sun shade and avoidance of smoking are the common personal radiation protection practices stated by the patients. Majority of the patients that engage in personal radiation protection practices are those with higher knowledge score. The knowledge about radiation and its potential detrimental effect on health has a role to play in adoption of personal radiation protection practices.

\section{CONCLUSION}

There is awareness of radiation in the general term but there is poor knowledge of the types of radiation, sources of radiation and the biological effects of radiation. Level of education plays an important role in the knowledge of radiation as most of the patients with tertiary education had good knowledge of radiation.

Patients awaiting radiological investigation had little or no knowledge about the type of investigation they undergo. In addition, they were not informed of the attendant health risk associated with some radiological investigations. Knowledge of radiation helps in the adoption of radiation protection practices.

It is hereby recommended that patients should be well educated by the clinician and radiation worker on the type of investigation and attendant radiation risk associated with the requested investigations.

\section{REFERENCES}

1. Faiz, M. K. ed. (1994). The Physics of Radiation Therapy. Second ed: Lippincott Williams \& Wilkins.

2. Ng, K. H. (2003). Non-ionizing radiations-sources, biological effects, emissions and exposures. In Proceedings of the international conference on non-ionizing radiation at UNITEN, 1-16.

3. Bushberg, J. T., Seibert, J. A., Leidholdt Jr, E. M., \& Boone, J. M. (2002). The Essential Physics of Medical Imaging, Lippincott Williams \& Wilkins. Philadelphia, USA.

4. Briggs-Kamara, M. A., Okoye, P. C., \& OmuboPepple, V. B. (2013). Radiation safety awareness among patients and radiographers in three hospitals in Port Harcourt. Am J Sci Ind Res, 4(1), 83-88.

5. Sin, H. K., Wong, C. S., Huang, B., Yiu, K. L., Wong, W. L., \& Chu, Y. C. T. (2013). Assessing local patients' knowledge and awareness of radiation dose and risks associated with medical imaging: a questionnaire study. Journal of medical imaging and radiation oncology, 57(1), 38-44.

6. Geofery, L., Basirat, M., Eze, C. U., Chigozie, N. I., Auwal, A., Kalu, O., ... \& Mathew, A. G. (2015). Evaluation of the knowledge and awareness of non-ionizing radiation among final year students of college of medical science university of Maiduguri. International Research Journal of Pure and Applied Physics, 3(3), 8-14.

7. Temaugee, S. T., Daniel, T. A., Oladejo, K. O., \& Daniel, S. (2014). Assessment of Public Awareness of the Detrimental Effects of Ionizing Radiation in Kontagora, Niger State, Nigeria. International Journal of Science and Technology, 4(7), 22243577.

8. Slovic, P. (1996). Perception of risk from radiation. Radiation protection dosimetry, 68(3-4), 165-180.

9. Samet, J. M. (1997). Epidemiologic studies of ionizing radiation and cancer: past successes and future challenges. Environmental health perspectives, 105(suppl 4), 883-889.

10. Borgen, L., Stranden, E., \& Espeland, A. (2010). Clinicians' justification of imaging: do radiation issues play a role?. Insights into imaging, 1(3), 193-200.

11. Ahidjo, A., Garba, I., Mustapha, Z., Abubakar, A. M., \& Usman, U. A. (2012). Referring doctors knowledge about radiation doses in patients undergoing common radiological examinations. $J$ Med Med Sci, 3(4), 222-225.

12. Sani, K. G., Jafari, M., Mohammadi, M., Mojiri, M., \& Rahimi, A. (2009). Iranian physicians' knowledge about radiation dose, received by patients in diagnostic radiology. International Journal of Radiation Research, 6(4), 207-212.

13. Shiralkar, S., Rennie, A., Snow, M., Galland, R. B., Lewis, M. H., \& Gower-Thomas, K. (2003). Doctors' knowledge of radiation exposure: questionnaire study. Bmj, 327(7411), 371-372.

14. Yücel, A., Karakaş, E., Bülbül, E., Koçar, İ., Duman, B., \& Onur, A. (2009). Knowledge about ionizing radiation and radiation protection among patients awaiting radiological examinations: a cross-sectional survey. The Medical Journal of Kocatep, 10:25-31.

15. Wright, C. Y., Norval, M., Summers, B., Davids, L., Coetzee, G., \& Oriowo, M. O. (2012). The impact of solar ultraviolet radiation on human health in sub-Saharan Africa. South African Journal of Science, 108(11-12), 45-51.

16. Congdon, N., West, S. K., Buhrmann, R. R., Kouzis, A., Munoz, B., \& Mkocha, H. (2001). Prevalence of the different types of age-related 
cataract in an African population. Investigative ophthalmology \& visual science, 42(11), 24782482.

17. Hill, J. C. (1985). The prevalence of corneal disease in the coloured community of a Karoo town. South African medical journal= SuidAfrikaanse tydskrif vir geneeskunde, 67(18), 723727.

18. Ashaye, A. O. (1991). Pterygium in Ibadan. West African journal of medicine, 10(3-4), 232-243.

19. Nwosu, S. N. (1998). Ocular problems of young adults in rural Nigeria. International ophthalmology, 22(5), 259-263.

20. Strauss, N., Mathee, A., Robertson, P., \& Blignaut, R. (1991). Sunscreen use and environmental awareness among beach-goers in Cape Town, South Africa. Public health reviews, 19(1-4), 209217.
21. Lucas, R. (2010). Solar ultraviolet radiation: Assessing the environmental burden of disease at national and local levels. World Health Organization (WHO Press).

22. Guy, C. Y., \& Diab, R. D. (2002). A health risk assessment of ultraviolet radiation in Durban. South African Geographical Journal, 84(2), 208-213.

23. Mohammed, A. Z., Edino, S. T., Ochicha, O., Gwarzo, A. K., \& Samaila, A. A. (2008). Cancer in Nigeria: a 10-year analysis of the Kano cancer registry. Niger J Med, 17(3), 280-284.

24. Mqoqi, N., Kellett, P., Sitas, F., \& Jula, M. (2004). Incidence of histologically diagnosed cancer in South Africa, 1998-1999. Johannesburg: National Cancer Registry of South Africa, National Health Laboratory Service, 31-33. 